\title{
25 Research Soure \\ Impacts of Stone Bund on Soil Quality in Masha-Deniba Micro-water Shed Loma woreda Dawuro Zone of Southern Ethiopia
}

Kero Alemu Danano ( $\nabla$ kerobonga@gmail.com )

Wolaita Sodo University https://orcid.org/0000-0002-6858-9072

Fanuel Laikemariam Laikemariam

Wolaita Sodo University

Research

Keywords: Topographic Position, Stone bund Age, Stone Bund, Soil Fertility

Posted Date: February 17th, 2020

DOI: https://doi.org/10.21203/rs.2.23721/v1

License: () (1) This work is licensed under a Creative Commons Attribution 4.0 International License. Read Full License 


\section{Abstract}

Background: - Land degradation is one of the major challenges in agricultural production Ethiopia. To combat the problem different Soil and Water Conservation (SWC) measures were introduced.

Methods: - This research was conducted in the Masha Deniba micro-watershed, Dawuro Zone, Southern Ethiopia aimed to assess impact of stone bund conservation on soil properties. This study compared the effects of stone bund age along landscape positions. Surface soil sample from 17 farms were collected and analyzed for soil bulk density (BD), organic matter (OM), total nitrogen (TN), pH and cation exchange capacity (CEC) of soil.

Result:- Results showed that farms treated with stone bunds showed improvement in soil chemical properties. For most parameters, the peak was obtained from stone bunds having 10 years age. The non- conserved plots had the lowest soil nutrients contents. Lower topographic position had shown higher nutrients contents than farms in upper topographic position. Overall, OC, TN, S and B contents were low in the watershed.

Conclusion: - From the finding we can conclude that stone bunds improved soil nutrient when compared to nontreated farm with the respect of age and landscape position. But constructing physical structures alone does not restore the soil fertility to the level that the crop is demanding. Thus, integration of physical conservation with agronomic and biological measures is highly recommended.

\section{Introduction}

Soil degradation can be described as deterioration of the physical, chemical and biological or economic properties of soil (Maitima and Olson, 2001). It is a principal environmental problem in Ethiopia which is manifested mainly in the form of soil erosion, soil fertility loss, and crop yield reduction. The excessive dependence of the Ethiopian rural population on natural resources, particularly land, as a means of livelihood is an underlying cause for land and other natural resources degradation (EPA, 1998). Soil degradation is caused and aggravated by erratic and erosive rain fall, topographical setup and inappropriate land use practices (Tamene et al. 2006; Ciampalini et al. 2008; Nyssen et al. 2009; Tesfaye and Fanuel, 2019).

Generally, water erosion is prominent in highlands of Ethiopia where erratic rainfall generate erosive runoff (Hurni, 1993). Various studies provided empirical evidence of the severity of the problem. For example, the Ethiopian highland reclamation study (EHRS) estimated 1.9 billion tons annual topsoil loss from the highlands due to water erosion, which is equivalent to $8 \mathrm{~mm}$ soil depth or $130 \mathrm{t} \mathrm{ha}^{-1}$ annual losses (FAO, 1986). Hurni (1993) also reported as much as $300 \mathrm{t}$ ha- 1 annual soil loss from croplands with average rates of $42 \mathrm{t} \mathrm{ha}^{-1}$. The extent of soil loss due to erosion in the Ethiopian highland is high varying between $42 \mathrm{t} \mathrm{ha}^{-1} \mathrm{y}^{-1}$ and $175.5 \mathrm{t} \mathrm{ha}^{-}$ ${ }^{1} \mathrm{y}^{-1}$ (Admasu et al., 2017).

The impact of soil erosion is complex leading to reduction in soil depth and moisture storage capacity together with soil-nutrient losses, and ultimately results in reduced agricultural production and productivity (Vancampenhout et al., 2006; Tesfaye and Fanuel, 2019). Soil erosion is a threat not only to agriculture but also to the economy, as the country's economy depends on agriculture.

Soil conservation is the only known way to protect the productivity of the land (Panda, 2007). Different SWC Measures are in place to mitigate land degradation problems. Their performance considerably varies based on 
type of structure, age of structure, land scape position (Tesfaye and Fanuel, 2019). Space occupied by soil and water conservation (SWC)structures, impediment to traditional farming activity, water logging problems, weed and rodent problems, huge maintenance requirement, are some of the reasons that cause farmers refrain from SWC works(Mitiku.et al., 2006).

Thus, this study aimed to examine the impact of SWC (Stone Bund) on selected soil physical and chemical properties as compared to non-conserved (Control) farm plots in Masha-Deniba Micro Water Shed in Zima Waruma kebele of Loma woreda.

The specific objectives include:

- To investigate the impacts of stone bunds and their age on soil physical and chemical properties;

- To investigate the effects of landscape positions on soil physical and chemical properties of the watershed.

Research questions

1. What impacts were observed on soil physical and chemical properties by the application of SWC technologies?

2. Is age of stone bund affect the soil fertility status?

3. Are there differences in soil properties among topographic positions?

\section{Materials And Methodology}

\subsection{Description of the study area}

The Loma woreda in Dawro Zone of Southern Nation, Nationalities and People Regional State (SNNPRS), Ethiopa is one of the highly eroded areas in the zone. Extent of soil degradation is threatening human livelihood and environmental integrity. The implementation of watershed based soil conservation activities are deep rooted when compared to others in Dawuro Zone (DZAND, 2016/17) and the study was selected our study. Loma woreda $\left(6^{0} 38^{\prime} .-7^{0} 07^{\prime} \mathrm{N}\right.$ and $\left.36^{0} 93^{\prime}-37^{0} 30^{\prime} \mathrm{E}\right)$, is located at $322 \mathrm{~km}$ and $504 \mathrm{~km}$, from region capital and Addis Ababa, respectively. The total area of the woreda is estimated to be $1200.30 \mathrm{Km}^{2}$ and it is surrounded by Mareka woreda in the North West, Gena Bossa North East, Gamo Gofa Zone in the South, Wolaita Zone in the East, and Essera Woreda in the West (Fig. 1).

Following the recommendation of experts (Zonal and woreda level), Zima Waruma watershed/ Masha-Deniba Micro-water Shed ( $6^{0} 54^{\prime} 00^{\prime \prime}-7^{0} 02^{\prime} 00^{\prime \prime} \mathrm{N}$ and $37^{0} 28^{\prime}-37^{0} 30^{\prime} \mathrm{E}$ ) covering $10.89 \mathrm{Km}^{2}$ was used for this study

(Fig. 1). The reason was that conservation measures have been applied in the area. In addition, traditional soil fertility maintenance techniques are also found.

\subsubsection{Agro-ecology and Soils}

Loma woreda has endowed with enormous and diversified land features that different elevation in-turn outfits the variability in rainfall and temperature. The altitude the study woreda ranges from 501 meter above sea level (m.a.s.I) around Omo river valley to 2012 m.a.s.I. According to the Southern Region Meteorological Agency, the 
mean annual temperature and rain fall of Loma Woreda during $2015 / 2016$ varied from $15.1^{\circ} \mathrm{C}-27.5^{\circ} \mathrm{C}$ and $500-$ $1800 \mathrm{~mm}$. respectively. The major soil type according to the report of Zonal Agricultural Department (2016/17) is nitisoil. The soil texture varied from silt to sandy texture.

The agro ecology according to traditional classification system includes Kolla (i.e., low land), Woyina Dega (i.e., mid highland) and Dega (i.e., high land). About $41 \%$ of the zonal land is lies under WeynaDega ecological zones, Kolla covers about $38 \%$ and Dega agro-ecological zone constitutes $21 \%$ of the total agro-ecological zones. Those three agro-ecological zones are suitable for agricultural production and human settlement.

\subsubsection{Farming System}

The means of livelihood is based on mixed crop-livestock agriculture where it is dominantly rainfed and subsistence. The major crops under rain fed condition include: maize (Zea mays), tef (EragrostistefZucca), potato (Solanumtuberosum), enset (Enseteventricosum), coffee (Coffeaarabica) and the dominant natural vegetations are mainly broad- leafed forest like Wanza(Cordials Africana), Weira(Olean Africana), Bamboo (Arundineria) Grawa (Vernoniaspecious) Shola (FicusSychmorise), Sobo, Woybeta, Badana and Acacia tree specious are the dominant one. Deforestation in search of additional farm land and income, land degradation, inappropriate land use and land and water management practices, are among the common challenges to the sustainability of the agricultural systems (Dawuro Zone Agriculture and Natural Resource Department Report 2016/17).

\subsubsection{Socio-Economic Characteristics}

The demographic and socio-economic description highlights based on 17 respondent households. Gender result indicated that about $94.1 \%)(n=16)$ were headed by male and $1(5.9 \%)$ households were headed by female out of which $47 \%(n=8)$ of the households have no formal education and $53 \%(n=9)$ of respondents attended elementary school. As far as the marital status of the heads of household is concerned, 16 (94.1\%) married (still living together and $1(5.9 \%)$ of the household heads were widowed in relation to this the family size of the respondents showed that $23.5 \%$ had $5-7$ family, $41.2 \%$ had $8-10$ families, $29.4 \%$ had above 11 and only $1 \%$ of the household heads had between 2-4 families. Overall, the average family size of the household heads was 5.5. In contrary of that huge family size; land owning can be characterized that $69 \%$ of the household heads have the land category of $0.125-05$ ha, $22 \%$ of the household heads were having 0.6-1 ha while only $9 \%$ of household heads have 1.3 ha-2 ha. Land fragmentation has its own problem on achieving SWC practices.

\subsection{Research Design}

\subsubsection{Sampling Procedures and Sample Points}

Preliminary field survey in the watershed was carried out to identify representative farms. Stone bund is common in the area. Farmlands treated with stone bund but having different age after construction were selected from different topographic positions. Four farm lands having stone bund age of 3, 5, 7, 10, 12, 15 and 17 were selected. In addition, on farm land without stone bund is also included for comparison. Farm lands lie in three topographic positions such as upper positions (> 36\% slope), middle position (16 to 35\% slope) and lower topographic position (up to 15\% slope) were selected. Thus a total of 17 farm lands were identified for soil sample collection in collaboration with woreda experts and site extension worker. In addition, slope, socio- 
economic characteristics and other relevant information from each farmland was recorded using data collection sheet. Each farm land was also geo-referenced.

\subsection{Data collected}

Disturbed and undisturbed soil sample at a depth of 0-20 cm were taken using augur and core sampler, respectively. About 10 sub-samples from each farm were taken to form one kg composite sample. The sampling under stone bunds includes the area between the two successive structures whereas for non-conserved plots, the sampling refers to the area under cultivation which is found between successive farm boundaries. After soil processing (drying, grinding and sieving), soil physicochemical properties like texture, $\mathrm{pH}$, soil organic carbon $(\mathrm{OC})$, and macro and micronutrient contents and cation exchange capacity (CEC) were analyzed.

Soil texture was analyzed by Bouyoucous hydrometer method (Bouyoucous, 1951). Soil BD was determined by using the core method (Anderson and Ingram 1993). Soil pH was measured in water at soil to water ratio of 1:2.5 (Van Reeuwijk, 1992). Organic carbon content was determined by the volumetric method (Walkley and Black, 1934). Total N was determined by Kjeldahl Method. Available P, K, Ca, Mg, S, Bu, Cu, Fe and Fe were determined by the Mehlich-3 method. Soil analysis was conducted in Debire Zeit Horticoop and bulk density was analyzed in Wolaita Sodo University Soil Laboratory.

\subsection{Data Analysis}

The data was evaluated using descriptive statistics such as mean, standard deviation, minimum, maximum and median. To complement descriptive statistics, Pearson correlation, and regression analysis were performed. Variation in soil properties was also determined using the coefficient of variation (CV) and rated as low (<20\%), moderate (20-50\%) and highly variable (>50\%) according to Aweto (1982) cited in Amuyou et al. (2013). For the management purposes, interpretation was given using proper ratings. The data were subjected to general linear model procedure using the SPSS and Microsoft excel.

\section{Results And Discussion}

\subsection{Age of Stone Bunds and their Effect on Soil Property}

Particle size distribution with age of stone bund was in in the order of silt > sand > clay with loam and clay loam textural classes. This might indicate the homogeneity of soil forming process, similarity of parent materials and the presence of intensive soil management practices promoting further weathering (Panday et al., 2019). Soil bulk density (BD) varies between 1.31 to $1.49 \mathrm{gcm}^{-3}$ from 12 years and control farms, respectively (Table 1 ). The mean was $1.34 \mathrm{gcm}^{-3}$. Soil BD declined with age of stone bund (Fig. 2). This could be attributed to the effects of reduced soil loss through erosion; and addition of organic matter from plants. Similar results were reported by Tesfaye and Fanuel (2019) who indicated a decline in BD with age of soil bund. Soil BD was ideal for proper root development (Hazelton and Murphy, 2007). 
Table 1

Effects of Stone bund age on soil physical and chemical properties $(N=17)$

Stone bund Age (Year)

\begin{tabular}{|lllllllllll|}
\hline $\begin{array}{l}\text { Age of } \\
\text { SWC }\end{array}$ & 0 & 3 & 5 & 10 & 12 & Mean & Min & Max & StDe & $\begin{array}{c}\text { CV } \\
(\%)\end{array}$ \\
\hline Sand & 34 & 35.5 & 35.75 & 36 & 33 & 35.00 & 28.00 & 40.00 & 3.03 & 8.66 \\
\hline Clay & 26 & 24.5 & 26 & 23 & 30 & 25.88 & 18.00 & 38.00 & 5.02 & 19.38 \\
\hline Silt & 40 & 40 & 38.25 & 41 & 37 & 39.12 & 28.00 & 46.00 & 4.06 & 10.37 \\
\hline Texture & Loam & Loam & Loam & Loam & Clay & Loam & & & & \\
\hline BD & 1.49 & 1.36 & 1.31 & 1.34 & 1.31 & 1.34 & 1.10 & 1.51 & 0.12 & 9.22 \\
\hline pH & 7.08 & 7.05 & 7.08 & 7.27 & 7.16 & 7.13 & 6.82 & 7.44 & 0.16 & 2.30 \\
\hline OC & 1.49 & 1.94 & 1.73 & 2.39 & 2.02 & 1.99 & 1.39 & 2.71 & 0.39 & 19.81 \\
\hline TN & 0.11 & 0.16 & 0.16 & 0.20 & 0.16 & 0.17 & 0.11 & 0.23 & 0.04 & 20.81 \\
\hline P & 30.85 & 27.73 & 36.59 & 56.94 & 20.14 & 35.09 & 13.56 & 80.75 & 19.29 & 54.98 \\
\hline S & 6.79 & 10.84 & 12.27 & 13.69 & 8.57 & 11.08 & 6.79 & 17.74 & 3.28 & 29.65 \\
\hline Ca & 10.69 & 13.96 & 14.50 & 14.69 & 17.99 & 15.02 & 8.06 & 26.51 & 5.19 & 34.53 \\
\hline Mg & 1.94 & 2.55 & 2.60 & 2.88 & 2.71 & 2.64 & 1.83 & 4.25 & 0.65 & 24.75 \\
\hline K & 1.60 & 1.92 & 2.21 & 2.41 & 1.23 & 1.92 & 0.83 & 3.75 & 0.86 & 44.58 \\
\hline Na & 0.06 & 0.09 & 0.09 & 0.06 & 0.10 & 0.08 & 0.04 & 0.14 & 0.03 & 30.52 \\
\hline Cu & 0.61 & 1.10 & 1.10 & 0.97 & 0.75 & 0.96 & 0.14 & 1.68 & 0.34 & 35.89 \\
\hline Fe & 104.88 & 85.74 & 90.96 & 91.90 & 97.22 & 92.24 & 63.54 & 113.72 & 15.35 & 16.65 \\
\hline Mn & 228.46 & 283.19 & 273.88 & 297.73 & 227.91 & 268.19 & 196.27 & 349.52 & 45.60 & 17.00 \\
\hline Zn & 6.76 & 6.06 & 5.46 & 7.75 & 2.16 & 5.44 & 1.49 & 10.94 & 2.40 & 44.12 \\
\hline B & 0.36 & 0.48 & 0.57 & 0.94 & 0.14 & 0.52 & 0.01 & 1.21 & 0.36 & 69.26 \\
\hline Mo & 0.16 & 0.19 & 0.18 & 0.18 & 0.16 & 0.18 & 0.03 & 0.22 & 0.04 & 23.45 \\
\hline CN & 13.05 & 11.93 & 10.95 & 11.72 & 12.63 & 11.88 & 9.83 & 14.13 & 0.92 & 7.72 \\
\hline CEC & 17.72 & 22.37 & 22.03 & 22.41 & 31.77 & 24.24 & 16.69 & 44.31 & 7.99 & 32.97 \\
\hline PBS & 80.68 & 82.70 & 85.99 & 89.68 & 69.26 & 81.83 & 61.08 & 98.86 & 10.34 & 12.64 \\
\hline
\end{tabular}

Soil pH among age of stone bund varied between 7.05 (3 years) and 7.27 (10 years). The result revealed an increment in soil pH at 10 and 12 Years when compared to untreated farms (Fig. 2). These might be associated to the decrease of the loss of soil organic matter and exchangeable bases through soil erosion and runoff; and 
thereby increase soil $\mathrm{pH}$. This is also explained with positive and significant relationship with $\mathrm{OC}(r=0.71), \mathrm{Ca}(r$ =0.67), $\mathrm{Mg}(\mathrm{r}=0.78)$ and $\mathrm{K}(\mathrm{r}=0.63)$ (Appendix 1).

Soil organic carbon (OC) of farm lands with age of stone bunds showed low variability. The mean of OC (1.99\%) was between $1.49 \%$ and $2.39 \%$ from untreated and stone bund at 10 years (Table 1). It is noted that soil bunds in general, and with increasing age of bunds improved the soil OC of farms (Fig. 2). The mean total N (TN) (0.17) varied from 0.11 to $0.20 \%$ obtained from untreated and 10 years stone bund. The result almost followed the trends of soil OC (Fig. 4.9). This signifies that stone bunds restore eroded materials on their embankment. Reports by Tesfaye and Fanuel (2019), and Dulo et al. (2017) indicated that increasing age of structures enhanced soil OC when compared to non-conserved land.

Available $\mathrm{P}$ was found highly variable (CV > 50\%) among age of stone bunds that varies from 27.7 to $56.9 \mathrm{mg} / \mathrm{kg}$ (Table 1) from 3 years and10 years', respectively (Fig. 2). The high variability in available P content may reflect differences within age of stone bunds and soil management. Higher amount of available P from integrated soil bund for 5 years was reported by Tesfaye and Fanuel (2019). The authors explained that reducing soil erosion and runoff, and improved amount of soil OC might result an increased available P on integrated and 5 year age stone bund. Pearon correlation matrix also indicated the positive and significant relationship of available $\mathrm{P}$ with $\mathrm{OC}(\mathrm{r}=0.50), \mathrm{pH}(\mathrm{r}=0.55)$ (Appendix 1$)$. The sulfur content $\left(\mathrm{mgkg}^{-1}\right) \mathrm{ranges}$ from 6.79 (3 years age) to 13.69 (10 years age) with moderate variability (CV = 20-50\%). Available S has shown positive and significant relationship with $\mathrm{OC}(r=0.53)$ and $\mathrm{pH}(\mathrm{r}=0.55)$ (Appendix 1$)$. The restoration of soil OC and reduced rate of soil erosion and runoff could result an increased available $S$ stone bunds.

Exchangeable cat-ions among age of stone bunds showed moderate variability $(\mathrm{CV}=20-50 \%)($ Table 1$)$. Exchangeable calcium was dominant in the exchangeable site followed by $\mathrm{Mg}^{2+}, \mathrm{K}^{+}$and $\mathrm{Na}^{+}$. Overall stone bunds showed higher amount of exchangeable cat-ions, and the amount was also increasing with age of stone bund (Fig. 2). This might be attributed with improvements in $\mathrm{pH}$, soil $\mathrm{OC}$ and CEC of the soil. Pearson correlation matrix also showed the significant and positive relation exchangeable bases with OC, TN and CEC (Appendix 1). The mean soil micronutrient contents were in the order $\mathrm{Mn}>\mathrm{Fe}>\mathrm{Zn}>\mathrm{Mo}>\mathrm{Cu}>\mathrm{B}$, and their variability was low (Fe, and Mn), moderate (Cu, Zn, Mo) and high (B) (Table 1). Overall, the contents of $\mathrm{Cu}, \mathrm{Mn}$ and $\mathrm{B}$ were better under conserved farms and with increase age of stone bunds, whereas, Fe content declined with age of conserved farms. The CEC content (Cmolc/kg) ranged between 17.4 and 31.8 with mean value of 24.2 (Table 3). CEC has shown significant and positive relationship with soil pH $(r=0.54), \mathrm{OC}(r=0.64), \mathrm{Ca}(0.94)$ and $\mathrm{K}(0.74)$ (Appendix 1).

\subsection{Landscape Position and their Effects on Soil Properties}

The effect of landscape position averaged over stone bund is summarized in Table 2. Though not big, the amount of silt and clay has shown a decreasing trend towards upper positions whereas, sand content was increasing towards upper position. Overall, the textural class falls under clay loam (lower postion) and loam (middle and upper positions). Soil bulk density (BD) showed differences along landscape positions in which middle and upper positions exhibited lower BD (Table 1; Fig. 3). The better amount of organic carbon towards lower land scape positions might be linked to lower bulk density. The result is in line with the work of previous researchers (Lawal et al., 2014 and Gebreselassie et al., 2015) who reported an increased BD value with the slope. 
In the present study, most of measured parameters such as soil $\mathrm{pH}, \mathrm{OC}$, and total $\mathrm{N}, \mathrm{S}, \mathrm{Ca}, \mathrm{K}, \mathrm{Mg}, \mathrm{B}$, base saturation and CEC has shown a decreasing trend towards the upper topographic positons (Table 2; Fig. 3). The result regarding available $\mathrm{P}$ showed maximum value at middle $>$ lower $>$ upper position. However, Fe was found to have increasing content towards upper positions Table 2; Fig. 3).

In general, farms in the upper topographic position of the watershed, in most of the soil parameters had lower content than farms in the lower topographic position. This might be associated to downward movement with runoff water from top and accumulation at the bottom slope position. The work of other researchers (Fanuel et al., 2016; Khan et al., 2013;

3 Gebreselassie et al., 2015) also indicated the lower nutrient contents in upper than lower slope position which they have presumed to be due to soil erosion. This suggests the need to strengthen SWC in the upper parts of the watershed. 
Table 2

Landscape Position and Their Effects on Soil Properties ( $N=17)$

\begin{tabular}{|lllllllll|}
\hline Topo & Lower & Middle & Upper & Mean & Min & Max & StDe & CV (\%) \\
\hline Sand & 32.33 & 35.20 & 37.50 & 35.00 & 28.00 & 40.00 & 3.03 & 8.66 \\
\hline Clay & 27.67 & 26.40 & 23.67 & 25.88 & 18.00 & 38.00 & 5.02 & 19.38 \\
\hline Silt & 40.00 & 38.40 & 38.83 & 39.12 & 28.00 & 46.00 & 4.06 & 10.37 \\
\hline Texture & Clay Loam & Loam & Loam & Loam & & & & \\
\hline BD & 1.25 & 1.42 & 1.37 & 1.34 & 1.10 & 1.51 & 0.12 & 9.22 \\
\hline pH & 7.27 & 7.18 & 6.96 & 7.13 & 6.82 & 7.44 & 0.16 & 2.30 \\
\hline OC & 2.23 & 2.19 & 1.59 & 1.99 & 1.39 & 2.71 & 0.39 & 19.81 \\
\hline TN & 0.19 & 0.18 & 0.14 & 0.17 & 0.11 & 0.23 & 0.04 & 20.81 \\
\hline $\mathrm{P}$ & 38.87 & 45.73 & 22.43 & 35.09 & 13.56 & 80.75 & 19.29 & 54.98 \\
\hline $\mathrm{S}$ & 12.76 & 10.36 & 9.98 & 11.08 & 6.79 & 17.74 & 3.28 & 29.65 \\
\hline $\mathrm{Ca}$ & 19.48 & 15.39 & 10.25 & 15.02 & 8.06 & 26.51 & 5.19 & 34.53 \\
\hline $\mathrm{K}$ & 2.49 & 1.81 & 1.44 & 1.92 & 0.83 & 3.75 & 0.86 & 44.58 \\
\hline $\mathrm{Mg}$ & 3.26 & 2.63 & 2.04 & 2.64 & 1.83 & 4.25 & 0.65 & 24.75 \\
\hline $\mathrm{Na}$ & 0.10 & 0.06 & 0.08 & 0.08 & 0.04 & 0.14 & 0.03 & 30.52 \\
\hline $\mathrm{Cu}$ & 1.29 & 0.64 & 0.90 & 0.96 & 0.14 & 1.68 & 0.34 & 35.89 \\
\hline $\mathrm{Fe}$ & 77.71 & 99.05 & 101.10 & 92.24 & 63.54 & 113.72 & 15.35 & 16.65 \\
\hline $\mathrm{Mn}$ & 270.04 & 253.23 & 278.82 & 268.19 & 196.27 & 349.52 & 45.60 & 17.00 \\
\hline $\mathrm{Zn}$ & 5.29 & 6.20 & 4.96 & 5.44 & 1.49 & 10.94 & 2.40 & 44.12 \\
\hline $\mathrm{B}$ & 0.68 & 0.61 & 0.29 & 0.52 & 0.01 & 1.21 & 0.36 & 69.26 \\
\hline $\mathrm{Mo}$ & 0.20 & 0.15 & 0.17 & 0.18 & 0.03 & 0.22 & 0.04 & 23.45 \\
\hline $\mathrm{Si}$ & 577.52 & 618.03 & 523.86 & 570.49 & 404.58 & 725.16 & 87.38 & 15.32 \\
\hline $\mathrm{CN}$ & 11.81 & 12.09 & 11.77 & 11.88 & 9.83 & 14.13 & 0.92 & 7.72 \\
\hline $\mathrm{CEC}$ & 29.75 & 25.51 & 17.67 & 24.24 & 16.69 & 44.31 & 7.99 & 32.97 \\
\hline $\mathrm{PBS}$ & 85.27 & 81.75 & 78.47 & 81.83 & 61.08 & 98.86 & 10.34 & 12.64 \\
\hline & & & & & & & & \\
\hline
\end{tabular}

\section{Conclusions And Recommendation}

From this study, we can conclude that stone bunds improved soil nutrient when compared to non-treated farm. The effect of bund, in most cases, had shown improvements up to 10 years after construction. On the other hand, lower topographic position had higher nutrients contents implying that the upper ones are prone to soil 
erosion. Overall, farms in the watershed irrespective of age of stone bund and landscape positions had shown low contents of $\mathrm{OC}, \mathrm{TN}, \mathrm{S}$ and $\mathrm{B}$. These limitations were attributed to inadequate management practices. This indicates that constructing physical structures alone does not restore the soil fertility to the level that the crop is demanding. Thus, integration of physical conservation with agronomic and biological measures is highly recommended to improve soil quality.

\section{Abbreviations}

CEC

- Cat-ion Exchange capacity

GPS

- Geographic Positioning System

DZAND

- Dawuro Zone Agriculture and Natural Resource Department

OC

- Organic Carbone

SB

- Stone bund / soil bund

SWC

- Soil and Water Conservation

\section{Declarations}

Acknowledgements: - I acknowledge anonymous reviewers for their constructive comments in order to improve the manuscript and we would like to thank Wolaita Sodo University for financial support. We thank Ermiyas Elka for their support during sample collection. Our gratitude also goest to zonal and woreda experts and site extension workers for their assistance. We are very grateful for all assistance, knowledge, and experiences received from the farmers in Masha-Deniba Micro-water Shed Loma woreda Dawuro Zone of Southern Ethiopia.

\section{Availability of data and materials}

We declare that the data and materials presented in this manuscript can be made available as per the editorial policy of the journal.

\section{Consent for publication}

All data and information are generated and organized by the authors.

\section{Funding: -}

Not applicable for this manual.

Author contribution:- Designed and generated location maps and developments, undertake field survey, and write respective report, review and edit the manuscript, read and approved the final manuscript. 
Ethics approval and consent to participate: - not applicable because the data were taken from sampled households without naming them.

Competing interests:- The author declares that there is no competing interest.

\section{Publisher's Note}

Springer Nature remains neutral with regard to jurisdictional claims in published maps and institutional affiliations.

\section{References}

1. Adimassu,Mekonnen, C. Yirga, A. Kessler, (2014)Effect of soil bunds on runoff, soil and nutrient losses, and crop yield in the central highlands of Ethiopia Land Degradation.Dev., 25 (6) (2014), pp. 554-56

2. Amuyou, U. A., Eze, E. B., Essoka, P. A., Efiong, J., \& Egbai, O. O. (2013). Spatial variability of soil properties in the Obudu Mountain Region of Southeastern Nigeria. International Journal of Humanities and Social Science, 3(15): 145-149.

3. Anderson, J. M., \& Ingram, J. S. I. (Eds.) (1993). Tropical soil biology and fertility: A handbook of methods (2nd ed.). Wallingford: CAB Internationa

4. Aweto A. O. (1982). Variability of upper slope soils development under sandstones in south western Nigeria Geographic journal; 25:27-37.

5. Bo uyoucos, G. J. 1951. A recalibration of the hydrometer method for making mechan i ca analysis of soil Is. Agronomy Journal 43:435-438.

6. DZANRMD:- Dawuro Zone Agriculture and Natural Resource Department Report 2016/17).

7. Dulo, S.O., Ouma, G.O., Tanui, F., Odira, M., Muturi, F., Wanguba, B., \& Ongech, D. (2017) Draft Turkana Water Audit Report. REACH Kenya.

8. Fanuel Laekemariam, K Kibret, T Mamo, E Karltun,(2016) Physiographic characteristics of agricultural lands and farmers' soil fertility management practices in Wolaita zone, Southern Ethiopia.

9. 1986. Watershed Management Field Manual: Slope Treatment Measures and Practices. FAO Conservation Guides-13/3.[online] RL:http://www.fao.org/ docrep/006/AD083e06.htm.1993.Soil Tillage in Africa: Needs and Challenges.

10. Gebreselassie Y, Anemut F, Addisu S (2015) The effects of land use types, management practices and slope classes on selected soil physico-chemical properties in Zikre watershed, North-Western Ethiopia. Springer Open J Env Sys Res 4:1-7 Hazelton and Murphy, 2007

11. Hazelton and Murphy, 2007Hurni H (1993) Land degradation, famines and resource scenarios in Ethiopia. In: Pimentel (ed.) World soil erosion and conservation. Cambridge University Press, pp27-62

12. Hurni H (1993) Land degradation, famines and resource scenarios in Ethiopia. In: Pimentel (ed.) World soil erosion and conservation. Cambridge University Press,pp27-62

13. Khan, A.D., Ghoraba, S., Arnold, J.G., and Di Luzio, M.: Hydrological modeling of upper Indus 468 Basin and assessment of deltaic ecology. International Journal of Modern Engineering 469 Research. 4(1):73-85, 2013. 
14. Lawal BA, Tsado PA, Eze PC, Idefoh KK, Zaki AA, Kolawole S (2014) Effect of slope Positions on some properties of soils under a TectonagrandisPlantation in Minna, Southern Guinea Savanna of Nigeria. Int $J$ Res Agric For 1(2):37-43J

15. Maitima, J.M. Olson, Guide to field methods for comparative site analysis for the land use change, impacts and dynamics (LUCID), Project Working Paper Series Number 15, International Livestock Research Institute, Nairobi, Kenya, 2001.

16. Mitiku, K. Herweg, B. Still hard, Sustainable Land Management-A New Approach to Soil and Water Conservation in Ethiopia, Land Resources Management and Environmental Protection Department, Mekelle University, Ethiopia, and Swiss Centre for Development and Environment, National Centre of Competence in Research (NCCR) North-South University of Bern, Switzerland, 2006, p. 269.

17. Nyssen J, Poesen J, Deckers J (2009) Land degradation and soil and water conservation in tropical highlands. Soil and Tillage Research, 103(2):197-202 Panda, 2007

18. Pandey CB, Srivastava RC (2019) Plant available phosphorus in home garden and native Forest soils under high rainfall in an equatorial humid tropic: a review. Plant Soil, 316(1-2):71-80

19. Tamene L, Vlek PLG, Park SJ, Dikau R (2006) Analysis of factors determining Sediment yield variability in the highlands of northern Ethiopia.Geomorphology,76:76-91

20. TesfayeTanto \&; Fanuel Environmental Systems Research volume 8, Article number: 13 (2019)

21. Van campenhout K, Nyssen J, Gebremichael D, Deckers J, Poesen J, HaileM, Moeyersons J(2006) Stone bunds for soil conservation in the northern Ethiopian highlands: Impacts on soil fertility and crop yield. Soil and Tillage Research,90(1-2):1-15

22. Walkley, A. and I. A. Black. 1934. An examination of Degtjareff method for determining soil organic matter and a proposed modification of the chromic acid titration method. Soil Sci. 37:29-37.

\section{Figures}




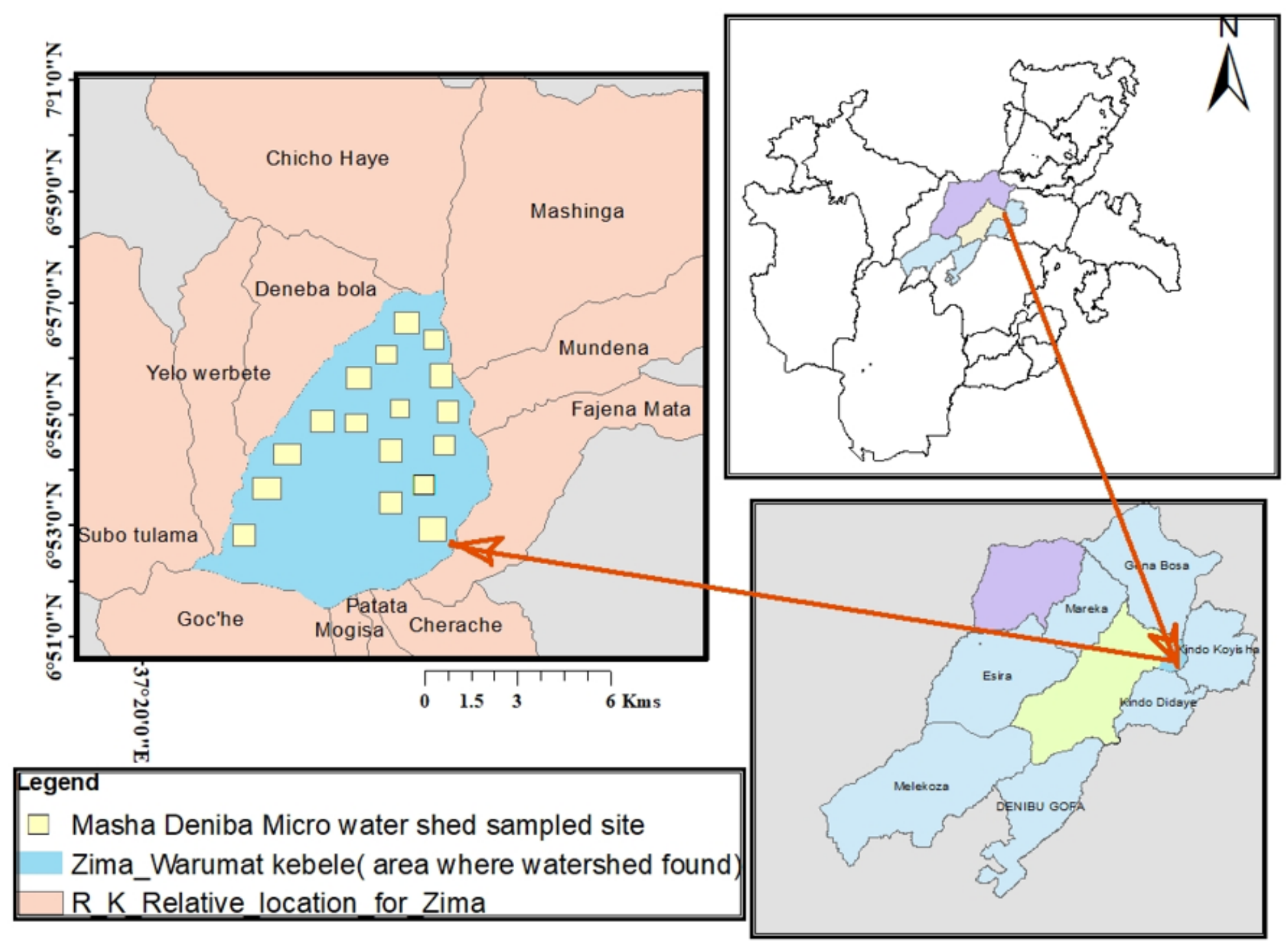

Figure 1

Location map of the study area produced by the researchers' 


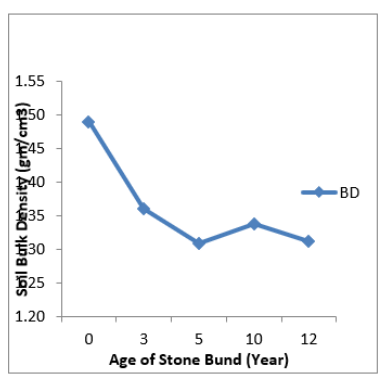

BD in reference of age of Stone Bund (Year)

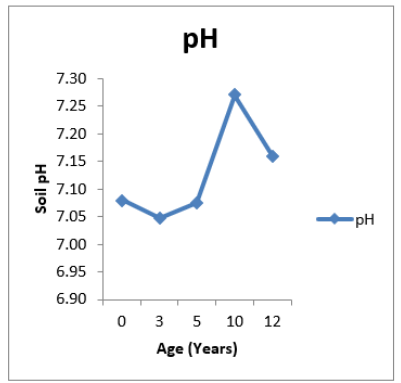

PH in reference age of Stone Bund

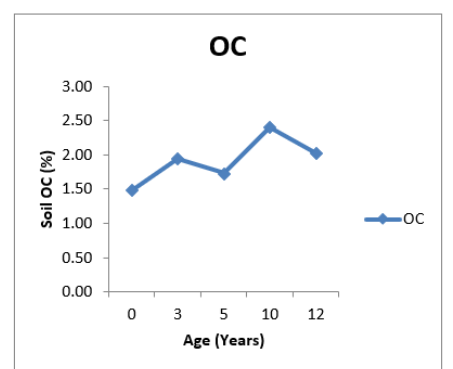

OC in reference age of Stone Bund

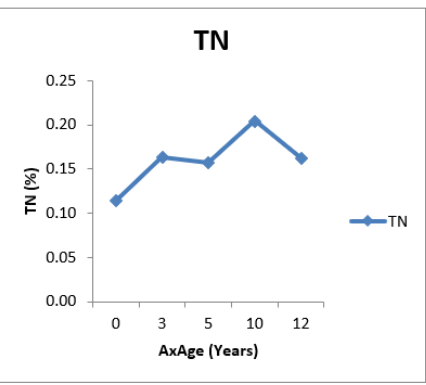

TN in reference age of Stone Bund

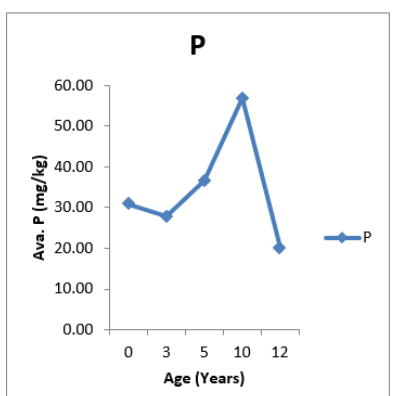

$P$ in reference age of Stone Bund

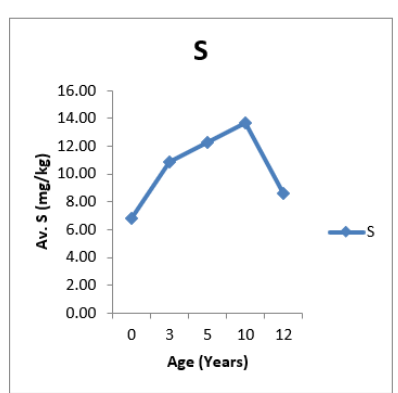

$S$ in reference age of Stone Bund

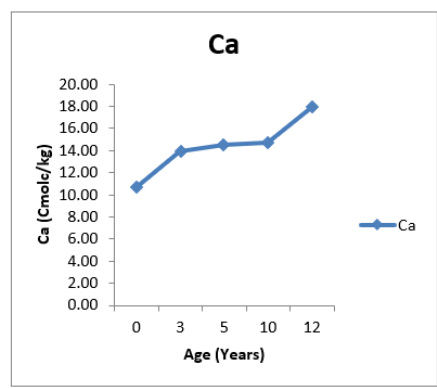

$\mathrm{Ca}$ in reference age of Stone Bund

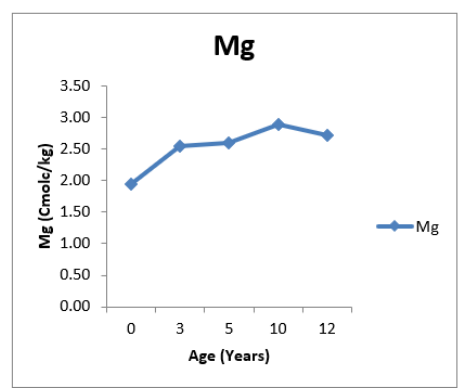

$\mathrm{Mg}$ in reference age of Stone Bund

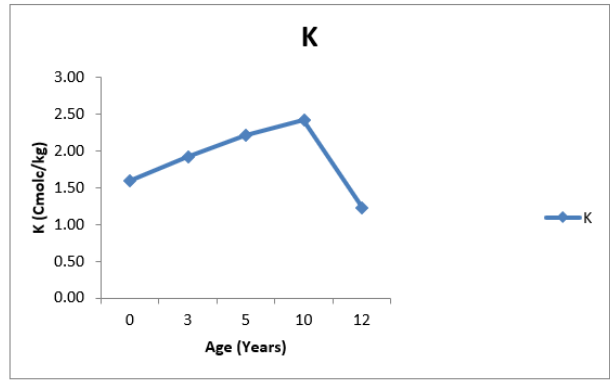

$K$ in reference age of Stone Bund

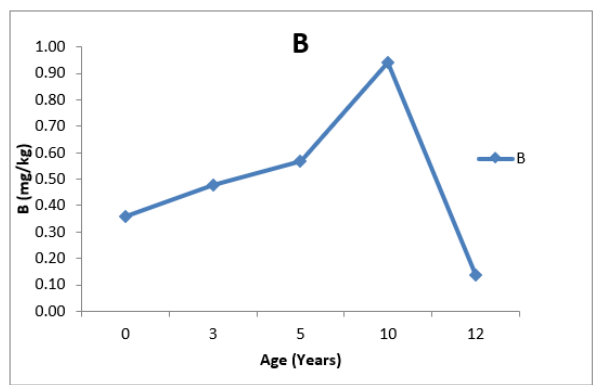

$B$ in reference age of Stone Bund

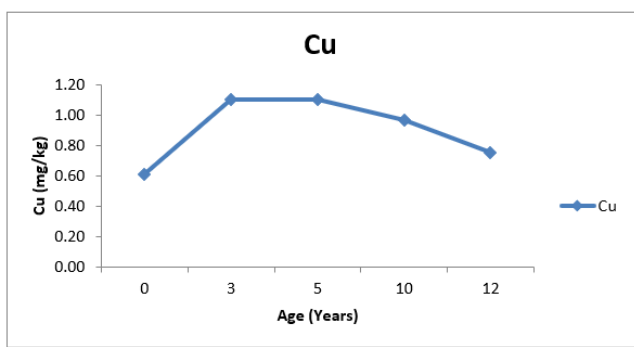

$\mathrm{Cu}$ in reference age of Stone Bund

\section{Figure 2}

Effects of Stone bund age on soil properties (Bulk Density, pH, OC, TN, Av. P, S, Ca, Mg, K, B and Cu) 

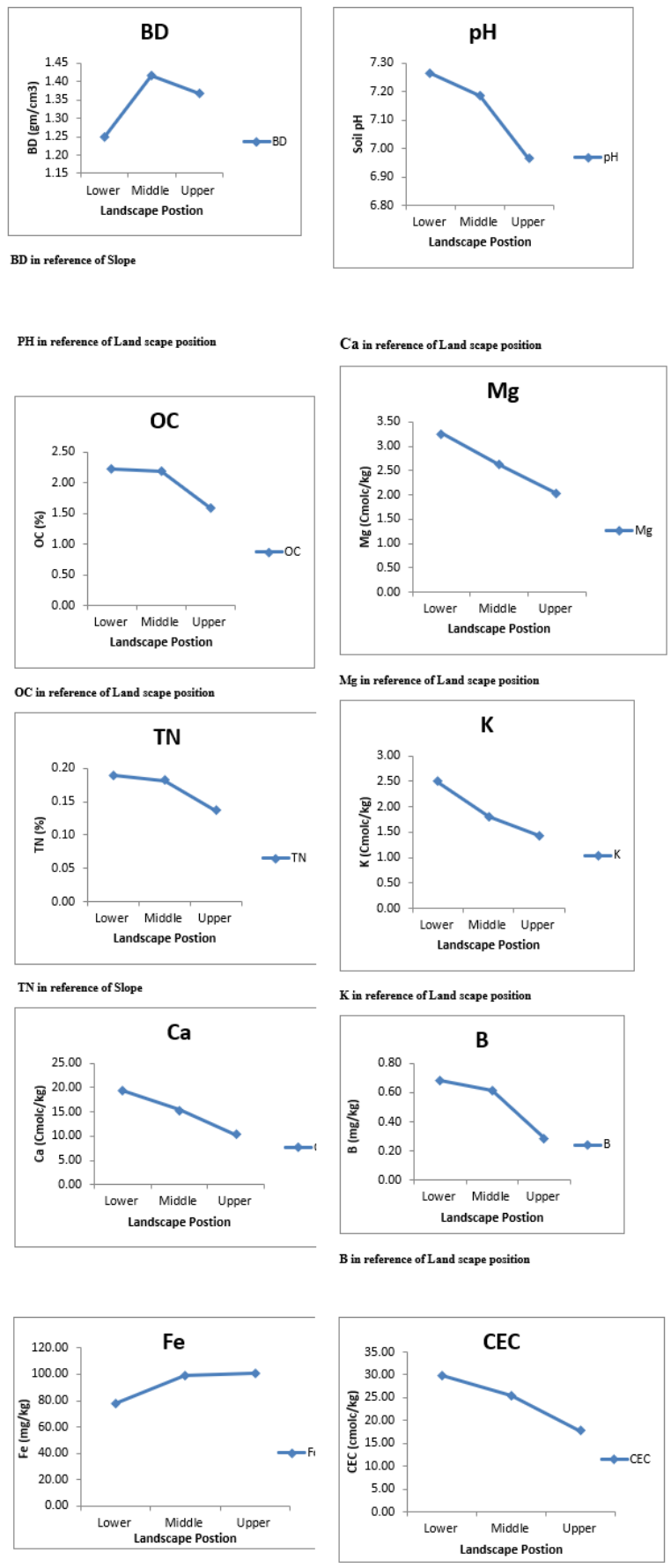

Fe in reference of Land scape position

CEC in reference of Land scape position

Figure 3

Effects of landscape position on Soil quality such as:- (soil bulk density, pH, OC, TN, Ca, Mg, K, B, Fe and CEC).

\section{Supplementary Files}

This is a list of supplementary files associated with this preprint. Click to download.

- Appendix.docx 